\title{
Comparative evaluation of enzyme activities and phenol content of Irish potato (Solanum tuberosum) grown under EM and IMO manures Bokashi
}

\author{
Hermann Désiré MBOUOBDA ${ }^{1,2^{*}}$, FOTSO ${ }^{1,2}$, Carole Astride DJEUANI ${ }^{2}$, \\ Melvis Osoh BALIGA ${ }^{1}$ and Denis Ndoumou OMOKOLO ${ }^{2}$ \\ ${ }^{I}$ Department of Biology, Higher Teachers Training College (HTTC), University of Bamenda, \\ PO Box 39, Bamenda, Cameroon. \\ ${ }^{2}$ Laboratory of Plant Biology, Department of Biological Sciences, Ecole Normale Supérieure (ENS), \\ University of Yaoundé 1; PO Box 47, Yaoundé, Cameroon. \\ *Corresponding author: mbouobda@yahoo.fr/mbouobda@hotmail.com; Tel: (237) 776954 88/94 651869
}

\begin{abstract}
Irish potato (Solanum tuberosum) is one of the world's most consumed staple. In order to develop natural fertilizers to increase Irish potato yield, we assessed the use of manures (EM Bokashi and IMO Bokashi, which are cocktail of beneficial bacteria; used as a soil remediation and health measure in many organic farms) on potato tubers in Bambili village in the North West Region of Cameroon, through evaluating biochemical parameters such as the phenol content, and the activities of peroxidase (POX), polyphenol oxidase (PPO) and pectinmethyl esterase (PME) enzymes. In this respect, a land of $18 \times 8 \mathrm{~m}^{2}$ with six plots of 18 beds each was used to cultivate the plant. The plant length and weight of tubers were quantified in the field. Relative to controls $(55.96 \pm 25.83 \mathrm{~cm})$, both EM and IMO Bokashi produced longer plants $(73.85 \pm 27.74 \mathrm{~cm}$ and $65.25 \pm 23.45 \mathrm{~cm}$ respectively) but between experimental plants, EM Bokashi led to heavier tuber weights (234 $\pm 132 \mathrm{~g}$ ) compared to IMO Bokashi. Interestingly, biochemical analyses showed the highest phenolic content and PME activity in plants treated with EM Bokashi. All treatments significantly increased POX activity while they decreased PPO activity. In addition, significant and positive correlations $(\mathrm{P}<0.01)$ were observed between stem length and PME activity independent of treatment. Plant treated with IMO Bokashi had significant and positive correlations between stem length and weight on the one hand and between stem length and biochemical parameters on the other hand. These findings showed that EM and IMO Bokashi treatments increased the phenol content, PME, PPO and POX activities during the growth of S. tuberosum and can thus be used to improve its growth and productivity.
\end{abstract}

(C) 2014 International Formulae Group. All rights reserved.

Keywords: Solanum tuberosum, phenol content, biochemical markers, Bokashi manures, productivity.

\section{INTRODUCTION}

The world's population is growing at a very rapid rate. Unfortunately, human demand for survival and sustainability is a great challenge to meet up with. Agricultural output, being one of the most important means of energy supply, especially to man, other herbivores and omnivores needs an increase in supply to meet up with their growing population. Irish potato (Solanum 
tuberosum) is a critical crop in terms of food security in the face of population growth and increased hunger rates. It is consumed by more than a billion people worldwide and is the third most important food crop after rice and wheat in terms of human consumption (Fontem et al., 2004). Despite the increase in potato production in the tropics, the amount of potato that is presently being produced in Cameroon is less than a third of the estimated production and its yield varies from 3.3 - $6.7 \mathrm{t} / \mathrm{ha}$ (Njualem et al., 2010); even though, significant quantities are exported to neighboring countries such as Gabon, Equatorial Guinea, Central African Republic and Chad (Demo, 2002; Fontem et al., 2004).

The low yield in the tropics has been attributed to poor agronomic practices, low use of inputs especially fertilizers and low soil fertility, limited access to good quality seeds (Muthoni and Nyamongo, 2009). It is estimated that more than $50 \%$ increase in yield is due to chemical fertilizers. The excessive use of chemical fertilizers has polluted the environment to a great extent and the food produced under such farm management technique may not be safe or of good quality.

Public awareness to this problem has shifted the approach towards some alternative measures (Shaxson, 2006). Organic farming offers an alternative that can eliminate many of the problems of conventional agriculture and has potential benefits in improving food quality and safety (Giles, 2004), promoting soil structure and function (Pulleman et al., 2003), alleviating environmental stress and enhancing soil biodiversity (Oehl et al., 2004).

The ultimate goal of sustainable agriculture is to develop farming systems that maintain natural resources such as soil and water, and that ensure food safety and quality. Microorganisms are very essential in improving soil health and fertility. Therefore, they play a great role in plant productivity. This makes them very important in maintaining soil fertility (Daly, 2004). Effective microorganisms consists of co-existing microorganisms which improve crop growth by increasing photosynthesis, producing bioactive substances such as hormones and enzymes, controlling soil diseases and accelerating decomposition of lignin material in the soil (Higa, 2000). Indigenous microorganisms consist of small naturally occurring soil microbes that are collected from the local area to be cultivated and then used to breakdown the complex organic molecules into the simple organic molecules and inorganic nutrients such as amino acids, vitamins and antioxidants. These microorganisms contribute to enhanced plant growth. During growth and development of plants, some enzymes and other chemical substances are produced in response to changes that occur in the plants. Phenolics are secondary metabolites that are produced to protect plants from stress, wounds, ultra violet light and pathogens. The plant pectin methylesterase (PME) are enzymes that play a role in the modulation of cell wall, mechanical stability during fruit ripening, cell wall expansion, pollen germination and pollen tube growth, abscission, stem elongation, tuber yield, root development and loss of tissue integrity (Micheli, 2001). Peroxidase (POX) is an oxido-reductive enzyme that participates in cell wall building processes such as oxidation of phenols, suberization, lignification of plant during defense against pathogenic agents (Chittoor et al., 1999; Kolattukudy et al., 1992). POX is involved in induced resistance during injury, herbivore or pathogen attack or during exposure to stress. In plants, they catalyze the oxidation of $o$-diphenols in quinones during the formation of natural as melanin, 
lignin, suberin and tannins. Polyphenol oxidase (PPO) is an enzyme involved in the oxidation of polyphenols into quinones which are antimicrobial compounds. It is also involved in lignification of plant cell walls during microbial invasion. This enzyme equally takes part in reactions which culminate in wound - induced tissue browning and erecting physical barriers against parasites (Altunkaya et Gokmen, 2007).

The main objective of this study was to investigate the effect of EM and IMO Bokashi on some enzyme activities, phenol content, growth and yield of Irish potato (Solanum tuberosum).

\section{MATERIALS AND METHODS Study site}

This experiment was carried out in the research farm of Higher Teachers Training College (H.T.T.C), University of Bamenda, during the period from March to July 2011. This is located in the Tubah sub-division, Mezam division of the North West region of Cameroon (Latitude 5'99'0', north and Longitude $10^{\circ} 15^{\prime} 00^{\prime}$ ' east).

\section{Land preparation and manure application}

A piece of land was first cleared by using a cutlass and raked. Thereafter, the land was ploughed and beds were made using a hoe. The farm was divided into two rows, each having nine beds $(3 \mathrm{~m}$ long and $0.9 \mathrm{~m}$ wide), and a distance of $0.5 \mathrm{~m}$ between the beds. The experimental design was the randomized complete block design (RCBD) with three treatments and six replications: EM manure, IMO manure and control. Manures were applied twice: one week prior to planting and 5 weeks after planting when mulching was done. Weeds were controlled by pulling with the hand.

\section{Preparation of EM Bokashi}

The EM manure was prepared according to the method of Higa (1991). A mixture of $1 \mathrm{~kg}$ of white sugar, $20 \mathrm{~L}$ of chlorine free water and $1 \mathrm{~L}$ of commercial $\mathrm{EM}(\mathrm{EM} \AA)$ was added to $50 \mathrm{~kg}$ of rice bran and $50 \mathrm{~kg}$ of wheat bran and mixed with hands until the mixture was homogenous. The mixture was then put in a plastic tank, compressed and left unopen for seven days. After the seven days, the EM was ready and gave a sweet fermenting smell.

\section{Preparation of IMO Bokashi}

IMO manure was prepared using local farming field material and according to the method of Helen et al. (2006). Ten (10) liters of indigenous microorganism (IMO) stock was poured on $50 \mathrm{~kg}$ of rice bran and mixed with the hands to obtain $30 \%$ moisture. The moist rice bran was compressed in a plastic tank and kept for 7 days for fermentation.

\section{Measurement of growth parameters}

Stem length was measured with a measuring tape at 5 weeks after planting. This was done weekly up to seven weeks.

\section{Harvesting}

Tubers were harvested ninety days after planting when the leaves and stems had dried off. All the crops from all the plots were harvested on the same day. The number and weight of tubers for each treatment were recorded.

\section{Phenol analysis}

Extraction of phenolic compounds was performed as described by Mbouobda et al. (2010). Fresh leaves $(0.5 \mathrm{~g})$ were ground at 4 ${ }^{\circ} \mathrm{C}$ with $80 \%$ methanol, and then centrifuged at $6000 \mathrm{~g}$ for $15 \mathrm{~min}$ after $30 \mathrm{~min}$ incubation. Total content of phenolic compounds were determined using the Folin-Ciocalteu reagent according to the method described by Macheix et al. (1990). Results were expressed in $\mu \mathrm{g}$ equivalent of chlorogenic acid by reference to the standard ( $\left.\mu \mathrm{g} \mathrm{CA} \cdot \mathrm{mg}^{-1} \mathrm{FW}\right)$. 
Extraction of proteins and evaluation of pectin methyl esterase, peroxidase and polyphenol oxidase activities

Fresh leaves $(200 \mathrm{mg})$ were extracted with $3 \mathrm{ml}$ Tris-maleate buffer buffer $(0.1 \mathrm{M}$, pH 6.5) containing Triton $X-100\left(0.1\right.$ g. $\left.\mathrm{L}^{-1}\right)$ and centrifuged for $15 \mathrm{~min}$ at $6000 \mathrm{~g}$ after 1 hour incubation at $4^{\circ} \mathrm{C}$. The supernatant obtained was used as the crude protein extract.

PME activity was determined at 610 $\mathrm{nm}$, using a mixture of $2 \mathrm{ml}$ of $0.1 \mathrm{M}$ pectin solution and $75 \mu \mathrm{l}$ of extract. PME activity was expressed as enzymatic unit.mg ${ }^{-1}$ of fresh weight (EU.mg ${ }^{-1} \mathrm{FW}$ ). PPO activity was determined by measuring the oxidation of 0.2 $\mathrm{M}$ catechol at $420 \mathrm{~nm}$ in $0.1 \mathrm{M}$ sodium phosphate buffer (pH 6). Enzyme activity was expressed as enzymatic unit.mg ${ }^{-1}$ of fresh weight (EU. s $\left.{ }^{-1} \mathrm{mg}^{-1} \mathrm{FW}\right)$.

Peroxidase (POX) activity was assayed using a spectrophotometer at $470 \mathrm{~nm}$ using guaiacol as substrate. $25 \mu \mathrm{l}$ of enzyme extract was added to $2.5 \mathrm{ml}$ of reaction mixture containing $0.1 \mathrm{M}$ Tris - maleate buffer and 25 $\mathrm{mM}$ guaiacol. Reactions were initiated with $20 \mu \mathrm{l}$ of $\mathrm{H}_{2} \mathrm{O}_{2}(10 \%)$ and ascorbic acid $(0.25$ $\mathrm{mM}$ ) and stopped after 2min. Enzyme activity was expressed as enzymatic unit.minute ${ }^{-1} \cdot \mathrm{mg}^{-}$ ${ }^{1}$ of fresh weight $\left(\mathrm{EU} \cdot \mathrm{min}^{-1} \cdot \mathrm{mg}^{-1} \mathrm{FW}\right)$.

\section{Data analyses}

All data were expressed as the means \pm standard deviations (SD). The data were then compared using analysis of variance (ANOVA). Duncan test was used to compare means at the significant level of 0.05 . The Rho Spearman correlation was used to determine the correlation between all the parameters evaluated in the different treatments. All analyses were performed using SPSS 17 software.

\section{RESULTS}

\section{Stem length}

The length of stems increased gradually from week five to week nine but decreased slightly from week nine to week eleven (Table 1). In week five, IMO Bokashi recorded the longest stem $(37.14 \pm 15.11 \mathrm{~cm})$, while from weeks seven to nine, it was EM Bokashi $(61.1 \pm 27.56 \mathrm{~cm}$ to $70.20 \pm 26.79$ $\mathrm{cm})$. Control recorded the shortest values.

\section{Yields}

The average weight of tubers was significantly high $(\mathrm{p}<0.05)$ in EM Bokashi $\left(243.14 \pm 132.1 \mathrm{~kg}^{2} \mathrm{ha}^{-1}\right)$ relative to IMO Bokashi $\left(150.26 \pm 92.5 \mathrm{~kg} \cdot \mathrm{ha}^{-1}\right)$ and control $\left(143.28 \pm 116.69 \mathrm{~kg}^{-h^{-1}}{ }^{-1}\right.$ (Figure 1).

\section{Phenol content}

Phenol content significantly increased throughout the period of observation (Table 2). In weeks 5 and $7 \mathrm{EM}$ Bokashi induced in plants the greatest phenol content followed by control and then IMO Bokashi. In week 11, EM Bokashi $\left(75.74 \pm 5.90 \mu \mathrm{g}\right.$ CA.mg ${ }^{-1}$ FW) and IMO Bokashi $(72.70 \pm 4.59 \mu \mathrm{g}$ CA. $\left.\mathrm{mg}^{-1} \mathrm{FW}\right)$ significantly increased phenol content $(\mathrm{p}<0.05)$ relative to the control $\left(64.27 \pm 5.35 \mu \mathrm{g} \mathrm{CA} \cdot \mathrm{mg}^{-1} \mathrm{FW}\right)($ Table 2).

\section{Pectin methyl esterase (PME) activity}

There was a progressive increase in PME activity in all treatments (Table 3). No significant difference was observed between different treatments over time except week 7 where this activity was significant different between EM Bokashi and control plants.

\section{Polyphenol oxidase (PPO) activity}

The activity of PPO significantly dropped from week seven through week eleven with EM Bokashi, while IMO Bokashi showed different profiles with an increase of the PPO activity in weeks 5 and 11 , while decreasing it in week 7 (Table 4).

\section{Peroxidase (POX) activity}

Although peroxidase activity within treatments varied considerably over time, it showed a general increase from week five to week nine and a drastic decrease in week 
eleven for all the treatments (Table 5). Relative to the control, IMO Bokashi (29.93 \pm 1.63 EU.min $\mathrm{g}^{-1} \mathrm{FW}$ ) significantly induced ( $\mathrm{p}$ $<0.05)$ the highest POX activity followed by EM Bokashi treatment $(15.43 \pm 3.42$ EU. $\left.\min ^{-1} \mathrm{~g}^{-1} \mathrm{FW}\right)$.

\section{Correlation between parameters evaluated under different treatments}

In plants treated with EM, there was a strong positive and significant correlation between stem length and PME activity $\left(0.775^{* *}\right)$, stem length and POX activity $\left(0.775^{* *}\right)$ and stem length and phenol content $\left(0.8000^{*}\right)$. Similarly, a significant and positive correlation was found between weight of tubers and POX activity $\left(0.272^{*}\right)$ as well as between weight of tubers and PME activity $(0.705 *)$. Among biochemical parameters, there was a positive and significant correlation between phenol content and POX activity $\left(1.000^{* *}\right)$ as well as phenol content and PPO activity $(0.562 *)$. But a negative and significant correlation was observed between PPO activity and PME activity $(-0.100 * *)$ (Table 6).
In plants treated with IMO, positive and significant correlation between stem length and weight of tubers $\left(0.638^{*}\right)$; weight of tubers and POX activity $\left(0.405^{*}\right)$; weight of tubers and PME activity $\left(0.805^{*}\right)$ were observed. Also, a positive and significant relationship was shown between stem length and all the biochemical parameters $(0.800 *$ for phenol content, PPO activity, PME activity and $0.316^{*}$ for POX activity). Within the biochemical parameters, no positive and significant correlation existed except between the phenol content and POX activity $\left(0.923^{* *}\right)$ (Table 6).

In control plants, no significant relationship between the biochemical parameters was revealed except between phenol content and POX activity $\left(0.765^{*}\right)$. There were also positive and significant correlations between plant length and PME activity $\left(1.000^{* *}\right)$, plant length and phenol $\left(0.143^{*}\right)$, and tuber weights and phenol content $\left(0.403^{*}\right)$ (Table 6).

Table 1: Irish potato stems length $(\mathrm{cm})$ under different treatments and over time.

\begin{tabular}{lccc}
\hline Duration (Weeks) & EM Bokashi & IMO Bokashi & Control \\
\hline 5 & $36.67 \pm 19.37 \mathrm{~b}$ & $37.14 \pm 15.11 \mathrm{~b}$ & $30.51 \pm 15.46 \mathrm{a}$ \\
6 & $50.87 \pm 25.12 \mathrm{c}$ & $43.38 \pm 18.39 \mathrm{~b}$ & $41.14 \pm 19.37 \mathrm{a}$ \\
7 & $61.1 \pm 27.56 \mathrm{c}$ & $54.00 \pm 19.67 \mathrm{~b}$ & $45.4 \pm 22.56 \mathrm{a}$ \\
8 & $73.85 \pm 27.74 \mathrm{c}$ & $65.25 \pm 23.45 \mathrm{~b}$ & $55.25 \pm 28.13 \mathrm{a}$ \\
9 & $70.20 \pm 26.79 \mathrm{c}$ & $64.4 \pm 22.23 \mathrm{~b}$ & $53.83 \pm 23.86 \mathrm{a}$ \\
10 & $69.4 \pm 26.31 \mathrm{c}$ & $61.36 \pm 21.46 \mathrm{~b}$ & $54.71 \pm 27.71 \mathrm{a}$ \\
11 & $61.32 \pm 23.12 \mathrm{~b}$ & $63.45 \pm 24.19 \mathrm{c}$ & $55.96 \pm 25.83 \mathrm{a}$ \\
\hline \multicolumn{4}{l}{ Data with different letters for the same experimental time are significantly different $(\mathrm{P}<0.05)$ (Duncan test). }
\end{tabular}

Table 2: Irish potato phenol content $\left(\mu \mathrm{g}\right.$ CA. $\left.\mathrm{mg}^{-1} \mathrm{FW}\right)$ under different treatments and over time.

\begin{tabular}{llll}
\hline Duration (Weeks) & EM Bokashi & IMO Bokashi & Control \\
\hline 5 & $35.78 \pm 2.91 \mathrm{a}$ & $34.17 \pm 1.06 \mathrm{a}$ & $34.69 \pm 1.86 \mathrm{a}$ \\
7 & $35.50 \pm 0.94 \mathrm{a}$ & $34.10 \pm 3.14 \mathrm{a}$ & $34.22 \pm 1.94 \mathrm{a}$ \\
9 & $49.03 \pm 4.49 \mathrm{~b}$ & $51.55 \pm 4.61 \mathrm{c}$ & $46.40 \pm 1.21 \mathrm{a}$ \\
11 & $75.74 \pm 5.90 \mathrm{c}$ & $72.70 \pm 4.59 \mathrm{~b}$ & $64.27 \pm 5.35 \mathrm{a}$ \\
\hline \multicolumn{4}{c}{ Data with different letters for the same experimental period are significantly different $(\mathrm{P}<0.05)$ (Duncan test). }
\end{tabular}


Table 3: Irish potato PME activity $\left(\mathrm{EU} \cdot \mathrm{g}^{-1} \mathrm{FW}\right)$ under different treatments and over time.

\begin{tabular}{lccc}
\hline Duration (Weeks) & EM Bokashi & IMO Bokashi & Control \\
\hline 5 & $2.83 \pm 0.17 \mathrm{a}$ & $2.64 \pm 0.07 \mathrm{a}$ & $2.63 \pm 0.12 \mathrm{a}$ \\
7 & $3.21 \pm 0.11 \mathrm{~b}$ & $3.08 \pm 0.06 \mathrm{ab}$ & $2.76 \pm 0.12 \mathrm{a}$ \\
9 & $3.33 \pm 0.12 \mathrm{a}$ & $3.05 \pm 0.12 \mathrm{a}$ & $3.06 \pm 0.04 \mathrm{a}$ \\
11 & $3.34 \pm 0.10 \mathrm{a}$ & $3.29 \pm 0.08 \mathrm{a}$ & $3.11 \pm 0.09 \mathrm{a}$ \\
\hline \multicolumn{2}{l}{ Data with different letters for the same experimental period are significantly different $(\mathrm{P}<0.05)$ (Duncan test). }
\end{tabular}

Table 4: Irish potato PPO activity $\left(\mathrm{EU} \cdot \mathrm{g}^{-1} \mathrm{FW}\right)$ under different treatments and over time.

\begin{tabular}{lccc}
\hline Duration (Weeks) & EM Bokashi & IMO Bokashi & Control \\
\hline 5 & $1.47 \pm 0.22 \mathrm{~b}$ & $1.48 \pm 0.13 \mathrm{~b}$ & $1.14 \pm 0.09 \mathrm{a}$ \\
7 & $0.79 \pm 0.26 \mathrm{a}$ & $1.05 \pm 0.20 \mathrm{~b}$ & $1.41 \pm 0.19 \mathrm{c}$ \\
9 & $0.39 \pm 0.07 \mathrm{a}$ & $0.61 \pm 0.06 \mathrm{~b}$ & $0.62 \pm 0.06 \mathrm{~b}$ \\
11 & $0.14 \pm 0.12 \mathrm{a}$ & $0.38 \pm 0.10 \mathrm{~b}$ & $0.15 \pm 0.08 \mathrm{a}$ \\
\hline \multicolumn{4}{l}{ Data with different letters in the same experimental time are significantly different } \\
(P<0.05) (Duncan test).
\end{tabular}

Table 5: Irish potatoes POX activity (EU.min ${ }^{-1} \cdot \mathrm{g}^{-1} \mathrm{FW}$ ) under different treatments and over time.

\begin{tabular}{lccc}
\hline Duration (Weeks) & EM Bokashi & IMO Bokashi & Control \\
\hline 5 & $3.6 \pm 0.30 \mathrm{c}$ & $3.08 \pm 0.27 \mathrm{~b}$ & $2.3 \pm 0.34 \mathrm{a}$ \\
7 & $6.84 \pm 0.28 \mathrm{a}$ & $12.8 \pm 0.52 \mathrm{c}$ & $9.75 \pm 0.47 \mathrm{~b}$ \\
9 & $15.43 \pm 3.42 \mathrm{~b}$ & $22.93 \pm 1.62 \mathrm{c}$ & $10.03 \pm 0.52 \mathrm{a}$ \\
11 & $9.3 \pm 1.08 \mathrm{a}$ & $9.16 \pm 0.57 \mathrm{a}$ & $8.00 \pm 1.75 \mathrm{a}$ \\
\hline EM: Effective microorganisms, IMO: Indigenous microorganisms, Data with different letters in the same experimental \\
time are significantly different (P < 0.05) (Duncan test).
\end{tabular}

Table 6: Rho - spearman correlation between parameters evaluated under different treatments.

\begin{tabular}{|c|c|c|c|c|c|c|}
\hline EM B & Length & Weight & Phenol & POX & PPO & PME \\
\hline Length & 1.000 & & & & & \\
\hline Weight & 0.275 & 1.000 & & & & \\
\hline Phenol & $0.800^{*}$ & $-0.421 *$ & 1.000 & & & \\
\hline POX & $0.775 * *$ & $0.272 *$ & $1.000 * *$ & 1.000 & & \\
\hline PPO & $-0.544 * *$ & $-0.785^{*}$ & $0.562 *$ & $-0.544 * *$ & 1.000 & \\
\hline PME & $0.775^{* *}$ & $0.705^{*}$ & 0.226 & 0.544 & $-1.000 * *$ & 1.000 \\
\hline IMO B & Length & Weight & Phenol & POX & PPO & PME \\
\hline Length & 1.000 & & & & & \\
\hline Weight & $0.638^{*}$ & 1.000 & & & & \\
\hline Phenol & $0.800 *$ & $-0.421 *$ & 1.000 & & & \\
\hline POX & $0.316^{*}$ & $0.405^{*}$ & $0.923 * *$ & 1.000 & & \\
\hline PPO & $0.800^{*}$ & $-0.205^{*}$ & 0.431 & $-0.800 * *$ & 1.000 & \\
\hline PME & $0.800^{*}$ & $0.805^{*}$ & $-0.677 *$ & 0.200 & $-0.400 *$ & 1.000 \\
\hline Control & Length & Weight & Phenol & POX & PPO & PME \\
\hline Length & 1.000 & & & & & \\
\hline Weight & $-0.086 *$ & 1.000 & & & & \\
\hline Phenol & $0.143 *$ & $0.403^{*}$ & 1.000 & & & \\
\hline POX & 0.400 & $-1.000 * *$ & $0.765^{*}$ & 1.000 & & \\
\hline PPO & -600 & 0.400 & 0.657 & $-0.400 * *$ & 1.000 & \\
\hline PME & $1.000 * *$ & $-4.00 *$ & -0.345 & 0.400 & -0.600 & 1.000 \\
\hline
\end{tabular}




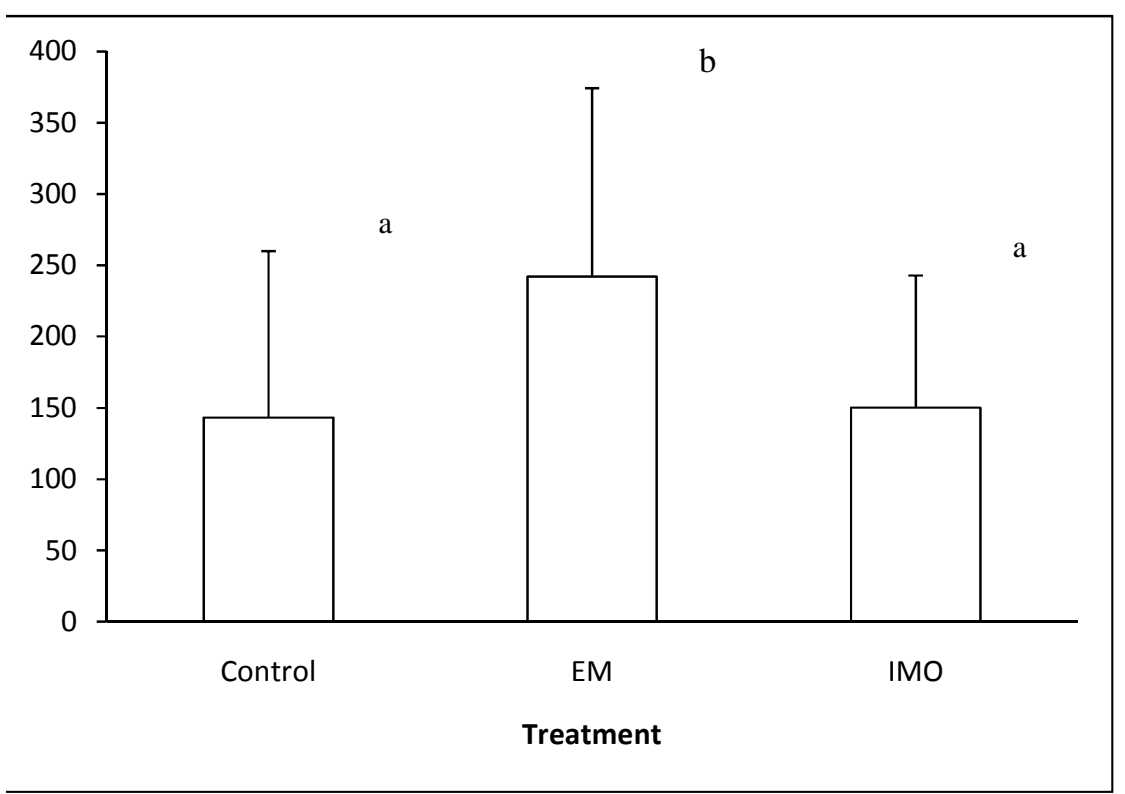

Figure 1: Average weight $\left(\mathrm{kg}_{\mathrm{h}} \mathrm{ha}^{-1}\right)$ of Irish potato tubers harvested per treatment. Data with different letters are significantly different $(P<0.05)$ (Duncan test) EM: Effective microorganisms, IMO: Indigenous microorganisms.

\section{DISCUSSION}

The purpose of this study was to evaluate the effect EM Bokashi and IMO Bokashi manures on some enzyme activities; phenol content; growth and productivity of Irish potato. Regarding the results, plants treated with EM Bokashi had the longest stems because of the continuous nutrient supply from the EM Bokashi. Also, application of EM greatly accelerated the breakdown (mineralization) of the organic matter in the Bokashi as well as in the soil which later release more nutrients into the soil making the nutrients available to plants for growth. According to Higa and Parr (1994), EM fertilizers are said to introduce microorganisms into the rhizosphere which play important roles with the purpose of improving soil quality, soil health, and the growth, yield and quality of plants. Plants treated with IMO Bokashi produced longer stems than those in the control plants. This is in conformity with Hoitink et al. (2008) who found that beneficial microorganisms in IMO significantly suppressed the activity of fungal pathogens in crops of mildly susceptible Rhododendron cultivars thereby enhancing growth.

The yield of tubers in terms of weight was high in treated soils compared to the control. EM Bokashi had a greater and significant yield than IMO Bokashi. Mineralization of soil through the breakdown the complex organic molecules into the simple molecules by these microorganisms could contribute to enhance plant growth and productivity. This is in line with other studies which showed positive yield effects of EM treatment in maize (Xu, 2001), beans (Sangakkara et al., 2008), onions (Chamberlain et al., 1998; Daly and Stewart, 1999) and tomato (Xu et al., 2000).

Phenolics are wide spread in plants and could be more or less accumulated depending on the stress condition (Dicko et al., 2006). The concentration of phenols is low at the beginning of the follow up because of the limited crop exposure to stress at this stage. There is a progressive increase in phenol content in all the treatments over time with 
positive and significant correlations $(\mathrm{P}<0.05)$ with plant length and weight of tubers. This increase could be due to the fact that phenol compounds provide health beneficial effects in plants and serve in counteracting reactive oxygen species (ROS) in order to survive and prevent molecular damage and damage by microbes, insects and herbivores (El Hassni et al., 2004). They are also involved in lignin biosynthesis as a physical barrier against several stresses (Belaqziz et al., 2008).

The continuous increase in PME activity from week 5 to week 11 positively and significantly correlates $(\mathrm{P}<0.01)$ with the stem length in all treatments as well as with weights in the treated plants. Growth processes like cell wall remodeling and root tip elongation are continuous processes which account for the continuous increase in PME activity of the plants in all the treatments (Pelloux et al., 2007). EM Bokashi showed a higher PME activity than IMO Bokashi thus causing a faster cell wall remodeling and root tip elongation. EM Bokashi and IMO Bokashi produced healthier and longer plants compared to controls and this could be associated to the higher PME activity. This is in conformity with the study of Keppler et al. (2004) who showed that in plants with high growth rates, PME facilitates demethylation of pectin by cross linking of pectin polymer chains and stabilizes the cell wall during expansion.

There was significant and negative correlation between PPO activity and both stem length and weight of tubers in plants treated with EM Bokashi. Studies have shown that PPO is induced in response to mechanical wounding, fungal and bacterial infections. The results obtained from PPO activity suggest that the plant treated with both Bokashi have been affected by wounding or pathogenic attack during the period of optimum growth. Control plants experienced the highest PPO activity in week 7 because of pathogen infection which would have activated the wound response pathway causing an increase in PPO activity for the plant to induce defense (Piyada et al., 2008).

POX activity generally increased in all the treatments during active growth. This activity was at its maximum during week seven to nine and therefore demonstrates the period of intensive activity in the plant. The rapid increase in POX activity, apart been associated to physiological process within the plants, could also be associated to the process of oxidative stress characterized by the production of reactive oxygen species that lead to cell wall suberization and lignification (Passardi et al., 2005).

\section{Conclusion}

Application of EM Bokashi and IMO Bokashi improved the growth and productivity of $S$. tuberosum. To prevent environmental pollution from extensive use of fertilizers, EM Bokashi and IMO Bokashi could be recommended to farmers for sustainable agriculture.

\section{ACKNOWLEDGEMENTS}

Authors are indebted to IMO student family of the first $2^{\text {nd }}$ batch of the Biology Department, HTTC Bambili, University of Bamenda, Cameroon for their participation in this research.

\section{REFERENCES}

Altunkaya A, Gökmen V. 2007. Effect of various inhibitors on enzymatic browning, antioxidant activity and total phenol content of fresh lettuce (Lactuca sativa). Food Chemistry, 107: 1173-1179.

Belaqziz M, Lakhal EK, Mbouobda HD, El Hadrami I. 2008. Land spreading of Olive Wastewater: effect on maize (Zea mays) crop. J. Agr., 7(4): 297-305.

Chamberlain TP, Daly MJ, Merfield CN. 1998. Utilisation of effective microorganisms in commercial organic agriculture - a case study from New Zealand. In: Fifth Int. Conference on Kyusei Nature Farming, Senanayake YDA, Sangakkara UR (eds), APNAN: Bangkok, Thailand 120-130. 
Chittoor JM, Leach JE, White FF. 1999. Induction of peroxidase during defense against pathogens. In Pathogenesis: Related Proteins in Plants, Datta SK, Muthukrishnan S (eds). CRC Press: Boca Raton, FL ; 291.

Daly MJ, Stewart DPC. 1999. Influence of effective Microorganisms (EM) on vegetable production and carbon mineralization- A preliminary investigation. J. Sust. Agri., 14: 2-3

Daly MJ. 2004. An overview of EM technology in New Zealand. Proceedings of the EM European conference 2004, held at Cultural Center de Meervaart Amsterdam, 18-20.

Demo P, Njualem DK, Koi J. 2000. Development of farmer-based seed potato system in Cameroon: Experiences form the first two years. African Potato Association Conference Proceedings. 5: $119-123$

Dicko HM, Gruppen H, TRaoré AS, Voragen AGJ, Van Berkel WJH. 2006. Phenolic compounds and related enzymes as determinants of sorghum for food use. Biotechnology and Molecular Biology Review., 1: 21-38

El Hassni M, Jaiti F, Dihazi A, Ait Barka E, Daayf F, El Hadrami I. 2004. Enhancement of defense response against Bayoud disease by treatment of date palm seedling with hypoagressive fusarium oxysporum isolate. J. Phytopathology, 152: $182-189$.

Fontem DA, Demo P, Njualem DK. 2004. Status of potato production, marketing and utilization in Cameroon. In: Advances in Root and Tuber Crops Technologies for Sustainable Food Security, Improved Nutrition, Wealth Creation and Environmental Conservation in Africa (Mahungu NM and Manyong VM Eds). Proceeding $9^{\text {th }}$ ISTRC-AB Symposium. 15 Nov. 2004. Mombasa, Kenya, 18-25.

Giles J. 2004. Is organic food better for us? Nat. (Lond.), 428: 796-797.
Helen J, Leopold G, Gerry G. 2006. A handbook of preparations, techniques and organic amendments inspired by nature farming and adapted to locally available materials and needs in the Western Visayas region of the Philippines. Natural farming manual. pp.1-37.

Higa T, Parr JF. 1994. Beneficial and Effective Microorganisms for a Sustainable Agriculture and Environment. Inter. Nat. Research Center: Atami, Japan; $16 \mathrm{p}$.

Higa T. 1991. Effective Microorganisms: A Biotechnology for Mankind. Sunmark Publishing Inc: Tokyo; 8-14.

Higa T. 2000. What is EM technology? EM World J., 1:1-6.

Hoitink HAJ, Gardener BBM, Miller SA. 2008. Current knowledge on disease suppressive properties of composts. CODIS: Compost and digestate: sustainability, benefits and impacts for the environment and plant production. Int. congress, CH-Solothurn. $27^{\text {th }}-29^{\text {th }}$ February 2008. 19-27.

Keppler F, Kalin RM, Harper DB, McRoberts JTG. 2004. Carbon isotope anomaly in the major plant $\mathrm{C}_{-1}$ pool and its global biogeochemical implications. Biogeosciences, 1: 123-131.

Kolattukudy PE, Mohan RM, Bajar A, Sherf BA. 1992. Plant peroxidase gene expression and function, Biochem. Soc. Trans. UK, 20:(2)333-337.

Macheix JJ, Billot J, Fleuriet A. 1990. Fruits Phenolics $\left(1^{\text {st }}\right.$ edn). CR Press, Inc: Boca. Raton, FL; 149-237.

Mbouobda HD, Fotso, Djocgoue PF, Omokolo ND, EL Hadrami I, Boudjeko T. 2010. Benzo-(1,2,3)-thiadiazole-7carbothioic S-methyl ester (BTH) stimulates defense reactions in Xanthosoma sagittifolium. Phytoparasitica, 38: 71-79.

Micheli F. 2001. Pectin methylesterases: Cell wall enzymes with important roles in plant physiology. Trends in Plant Science, 6: 414-419. 
Muthoni J, Nyamongo DO. 2009. A review of constraints to ware Irish potatoes production in Kenya. J. Horti. Forestry, 1(7): 98-102.

Njualem DK. 2010. Evaluation of potato (Solanum tuberosum L.) production and clonal screening for resistance to major diseases and yield characteristics in the western highlands of Cameroon. PhD thesis. University of Dschang, Cameroon. p138.

Oehl F, Sieverding Mäder EP, Dubois D, Ineichen K, Boller T, Wiemken A. 2004. Impact of long-term conventional and organic farming on the diversity of Arbuscular mycorrhizal fungi. Oecologia, 138: 574-583.

Passardi F, Cosio C, Penel C, Dunand C. 2005. Peroxidases have more functions than a Swiss army knife. Plant Cell Rep., 24: 255-265.

Pelloux J, Rusterucci C, Mellerowicz EJ. 2007. New insights into pectinmethylesterase structure and function. Trends in Plant Science, 12: 267-277.

Piyada T, Melkonian J, Wolfe DW, John C. 2008. Foliar PPO activity of NT plants also increased throughout development in response to water stress. Nanotechnology, 174(4): 693-703.
Pulleman MA, Jongmans I, Boum J. 2003. Effects of organic versus conventional arable farming on soil structure and organic matter dynamics in a marine loam in the Netherlands. Soil Use Manage, 19:157-165.

Sangakkara UR, Weerasekera P, Attanayake KB, Attanayake AMU. 2008. Inoculation affects nitrogen balances of composts and growth, yield and microflora of Phaseolus beans. In Cultivating the Future Based on Science. Proceedings of the Second Scientific Conference of the International Society for Organic Agriculture Research (ISOFAR). 1: 102-105.

Shaxson TF. 2006. Re-thinking the conservation of carbon, water and soil: a different perspective. Agron. Sustain. Dev., 26: 9-19.

Xu HL, Wang R, Mridha M. 2000. Effects of organic fertilizers and microbial inoculants on leaf photosynthesis and fruit yield and quality of tomato plants. J. Crop Protection, 3: 173-182.

$\mathrm{Xu}$ H. 2001. Effects of a microbial inoculants and organic fertilizers on the growth, photosynthesis and yield of sweet corn. $J$. Crop Production, 3(5): 183-214. 